\title{
Dust Source, Vertical Profile and Climate Impact by RegCM3 Regional Climate Model over West Africa during 2006
}

\author{
Dialo Diop $^{1 *}$, Demba Ndao Niang ${ }^{2}$, Mamadou Simina Drame ${ }^{1,2}$, Abdoulaye Ba1 \\ ${ }^{1}$ Département de Physique, Faculté des Sciences et Techniques, Université Cheikh Anta Diop de Dakar, Dakar, Sénégal \\ ${ }^{2}$ Laboratoire de Physique de l'atmosphère et de l'Océan Siméon Fongang, Université Cheikh Anta Diop, Dakar, Sénégal \\ Email: ^dialo.diop.ucad@gmail.com
}

How to cite this paper: Diop, D., Niang, D.N., Drame, M.S. and Ba, A. (2020) Dust Source, Vertical Profile and Climate Impact by RegCM3 Regional Climate Model over West Africa during 2006. Atmospheric and Climate Sciences, 10, 206-219.

https://doi.org/10.4236/acs.2020.102011

Received: February 13, 2020

Accepted: April 20, 2020

Published: April 23, 2020

Copyright (c) 2020 by author(s) and Scientific Research Publishing Inc. This work is licensed under the Creative Commons Attribution International License (CC BY 4.0).

http://creativecommons.org/licenses/by/4.0/

\begin{abstract}
This study aims to evaluate dust impact on climate parameters over the Sahel region by RegCM3 regional model during 2006. Indeed, aerosols are one of the main uncertainties in climate models. The aerosol optical depth (AOD) derived from RegCM3 model has been validated with various observed datasets. The aerosol sources are identified over North Algeria and East of Sahel (Bodele depression). Discrepancies are noted when considering dust temporal and spatial distribution. Dust season extends between March and October, with two peaks of AOD recorded in March (spring) and June (summer). The dust vertical distribution showed that the mineral aerosol layer is located between $850 \mathrm{hPa}$ and $300 \mathrm{hPa}(1.5 \mathrm{~km}$ to $7 \mathrm{~km})$. The RegCM3 model simulates fairly well the transport in the upper layers, especially in the Saharan Air Layer (SAL) during the summer. However, RegCM3 simulates poorly the transport and sedimentation of particles in the lower layers (below $2 \mathrm{~km}$ ). The investigation of dust radiative impact shows a general cooling. The maximum of radiative forcing is located around $18^{\circ} \mathrm{N}-20^{\circ} \mathrm{N}$, with values of about $-80 \mathrm{~W} / \mathrm{m}^{2}$ in June - August (JJA) and $-40 \mathrm{~W} / \mathrm{m}^{2}$ at the surface during March - May (MAM). This study also showed the indirect effect of dust with a decrease in precipitation about $-0.7 \mathrm{~mm} /$ day around $15-20^{\circ} \mathrm{N}$ during the rainy season.
\end{abstract}

\section{Keywords}

Dust, RegCM3, Sahel, Lidar, AERONET, Temperature, Rainfall, West Africa

\section{Introduction}

The African continent is the biggest dust source of the world with $40 \%$ of global 
emissions when considering tropospheric aerosols [1] [2] [3] [4] [5] and particles from biomass burning. The West African region is characterized by dust outbreaks throughout the year [6] and biomass burning in winter [7]. The African continent is not well equipped in terms of measurement tools for assessing the climate and its evolution. However, it is the continent where climate change impacts are felt the most (drought in 1970). Indeed, global models do not highlight regional specificities such as Sahara dust. Therefore, to better understand and study the variations of climate over Africa, the use of regional climate models is of great importance. These types of models have the advantage of using fine resolutions and taking into account local meteorological processes.

In West Africa, the years of continuous rain deficits are characterized by abnormalities in the dynamics of West African monsoon system, and a continuous increase in dust emissions. Several measurement campaigns (ABAT, AMMA) were conducted to study the impact of dust on regional climate [8]. In this study, we use the regional climate model RegCM3 to assess the impact of desert aerosols on climate over the Sahel in 2006. The model outputs have been validated with ground instruments and satellite observations. This validation study is followed by an estimation of dust impact on Sahel climate.

\section{Data and Methodology}

\subsection{The Regional Climate Model RegCM3}

Unlike the regional climate models, many global models were developed to simulate the summer cycle of desert dust [9] [10] [11]. Few dust studies using the regional climate models are available in the literature [12]. RegCM3 is a regional hydrostatic model developed at Abdu Salam Centre for Theoretical Physics (ICTP) [13]. Zakey et al. (2006) [14] have developed and tested in 2004 a dust module included in the ICTP Regional Climate RegCM3 [13] [15]. This dust module is widely described in [14] [16]. In this study, two sets of runs have been done: a control run (no dust effects, $\mathrm{AOD}=0$ ) and a dust run which takes into account dust radiative effects. The resolution of the model is $60 \mathrm{~km}$.

\subsection{Validation Data}

AERONET network data are the main validation products used in this study [7]. The stations (Figure 1) considered are: Banizoumbou (Niger), Agoufou (Mali), Ouagadougou (Burkina Faso) and Dakar (Senegal). AERONET instruments (photometers) provide the spectral optical thickness AT $550 \mathrm{~nm}$. The vertical distribution of dust is validated by the profiles of the lidar stationed in Dakar. The Moderate Resolution Imaging Spectrometer (MODIS) [17] [18] [19], the Multi-Angle Imaging Spectro Radiometer (MISR) sensors [20] and the Goddard Global Ozone Chemistry Aerosol Radiation and Transport (GOCART) are used to characterize the dust seasonal cycle [21]. 


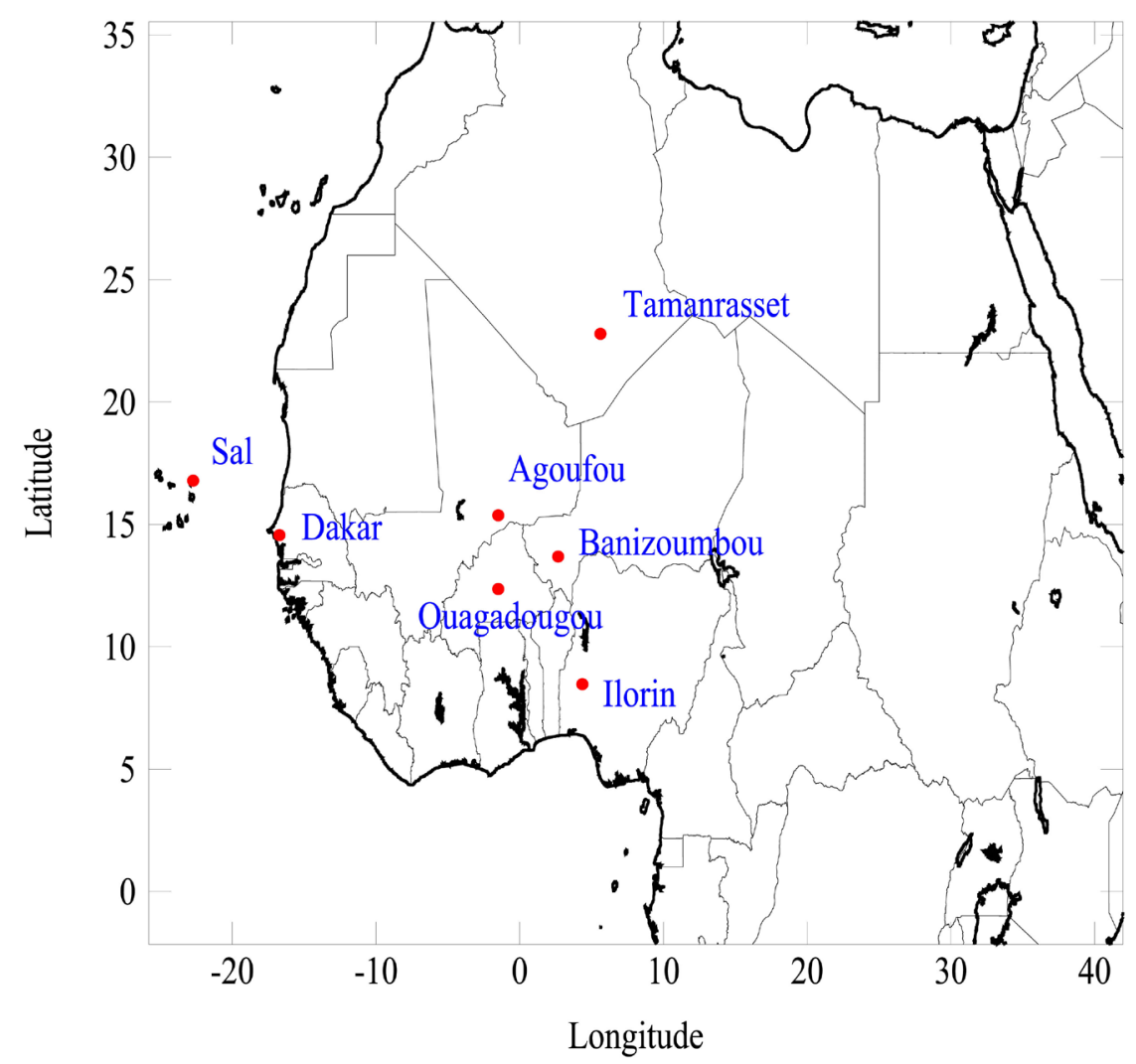

Figure 1. Representation of the study area (West Africa) with AERONET stations used.

\section{Results and Discussion}

\subsection{Validation of RegCM3 Regional Climate Model}

\subsubsection{Annual Seasonal and Daily Pattern of Dust}

We begin by showing in Figure 2, the annual average of aerosol optical depth (AOD) obtained with models (RegCM3 and GOCART) and by two radiometers on orbit (MODIS and MISR) in 2006. This annual AOD is used to identify the aerosol sources. Two source areas have been identified: one is the border between Mauritania (East) and North-Western Mali and the other is from Niger (North-East) to the Western of Chad near Bodele depression. These maximum are located between 15 and $20^{\circ} \mathrm{N}$ latitude and longitude about $8^{\circ} \mathrm{W}$ according to RegCM3; then GOCART and MISR locate these sources in the band $15^{\circ} \mathrm{N}$ $18^{\circ} \mathrm{N}$ and $15^{\circ} \mathrm{E}$. Besides MODIS, all other remote sensing sensors indicate clearly these source areas. And finally, we note that the models tend to overestimate the optical thickness (observations) especially for RegCM3.

Next we examine, the dust seasonal cycle in West Africa. Figure 3 shows the seasonal (March-April-May and June-July-August) cycle of AOD in West Africa using RegCM3 model and MISR measurements. Sources of aerosols (dust maximum) are mainly located at the border of Mauritania/Mali, southern Algeria and near to the Bodele depression (Chad). The seasonal distribution shows the predominance of dust during the wet season compared to dry season. Table 1 summarizes the mean annual AOD $(550 \mathrm{~nm})$ to MODIS, AERONET and RegCM3 
(a) : MISR

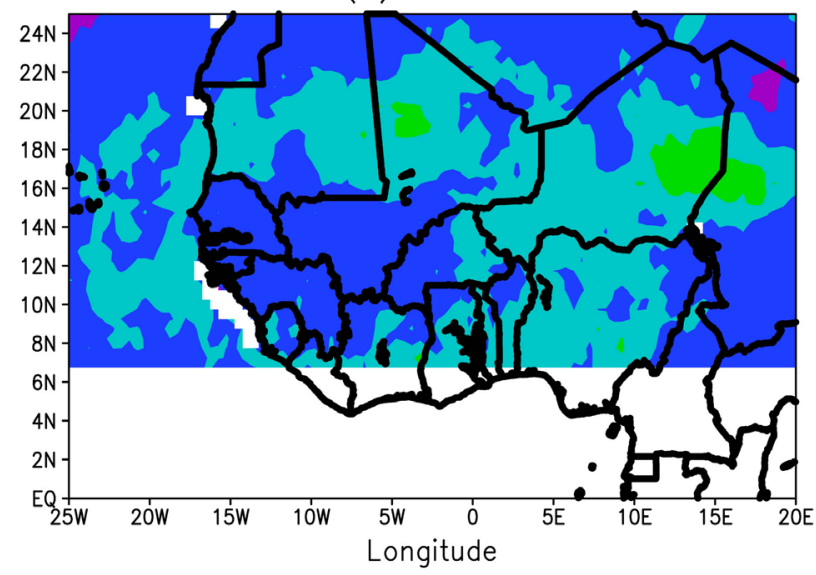

(b) : MODIS

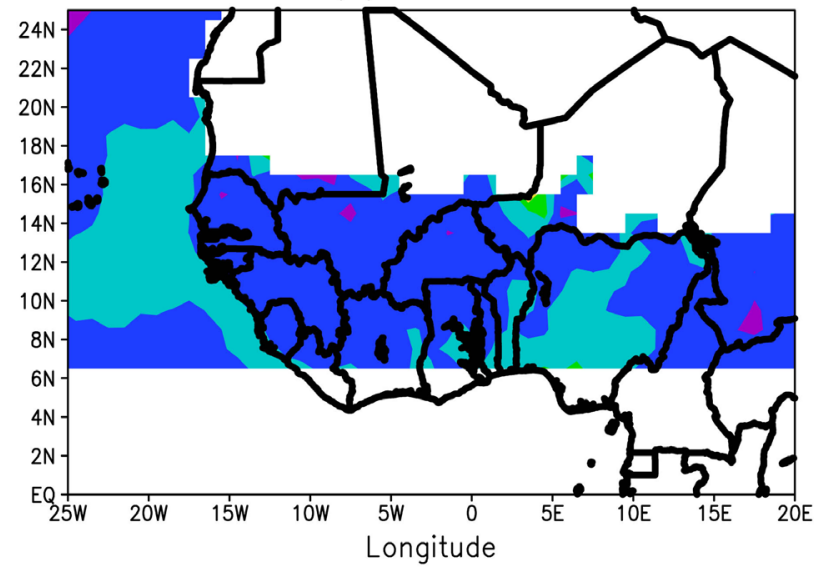

(c): $\operatorname{Reg} C M$

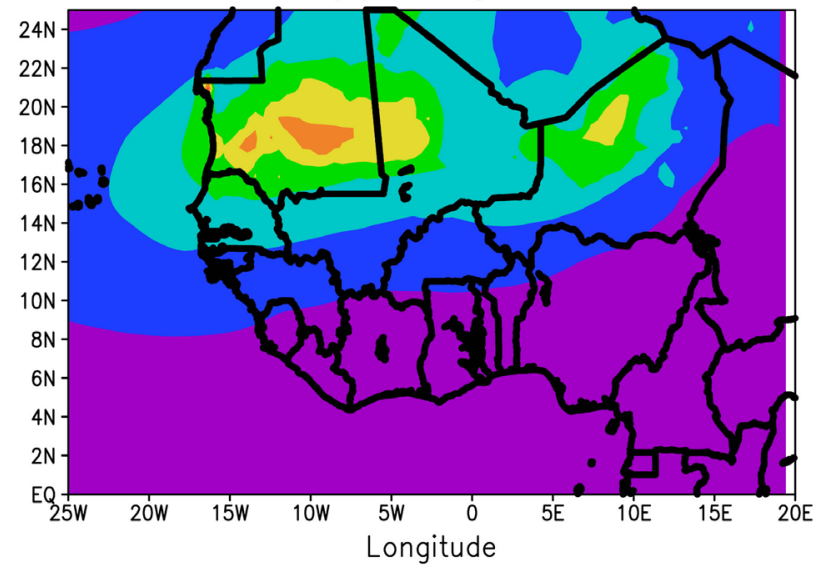

(d) : GOCART
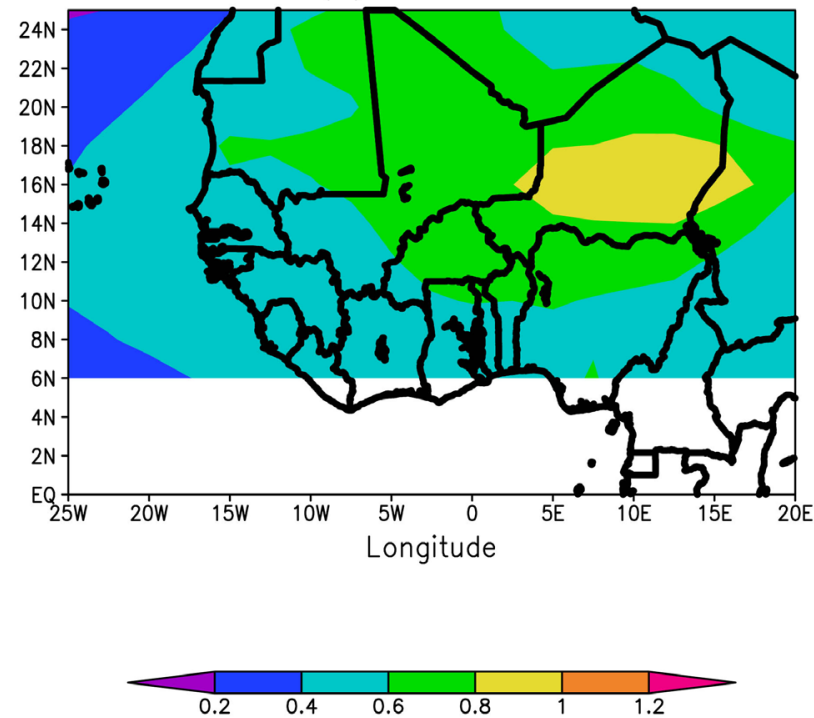

Figure 2. Annual averages of aerosols optical depth derived from models and observations in 2006 (Dust sources in Africa). The left figures represent the MISR observations (a) and MODIS (b); while those on the right are model outputs RegCM3 (c) and GOCART (d).

Table 1. Annuel average values of AOD from in situ measurement (AERONET), satellite sensor (MODIS) and model (RegCM3) for Banizoumbou, Agoufou, Ouagadougou and Dakar stations.

\begin{tabular}{cccc}
\hline AOD & AERONET & MODIS & RegCM3 \\
\hline Banizoubou & 0.54 & 0.31 & 0.36 \\
Agoufou & 0.53 & 0.37 & 0.28 \\
Ouagadougou & 0.48 & 0.35 & 0.45 \\
Dakar & 0.49 & 0.40 & 0.50 \\
\hline
\end{tabular}

for four stations in West Africa. Indeed, RegCM3 underestimates the dust loading compared to AERONET for the Eastern stations (Banizoumbou, Ouagadougou) and overestimates it in western stations (Dakar, Cape Verde). Overall, model results range between in situ measurements and satellite observations. For 

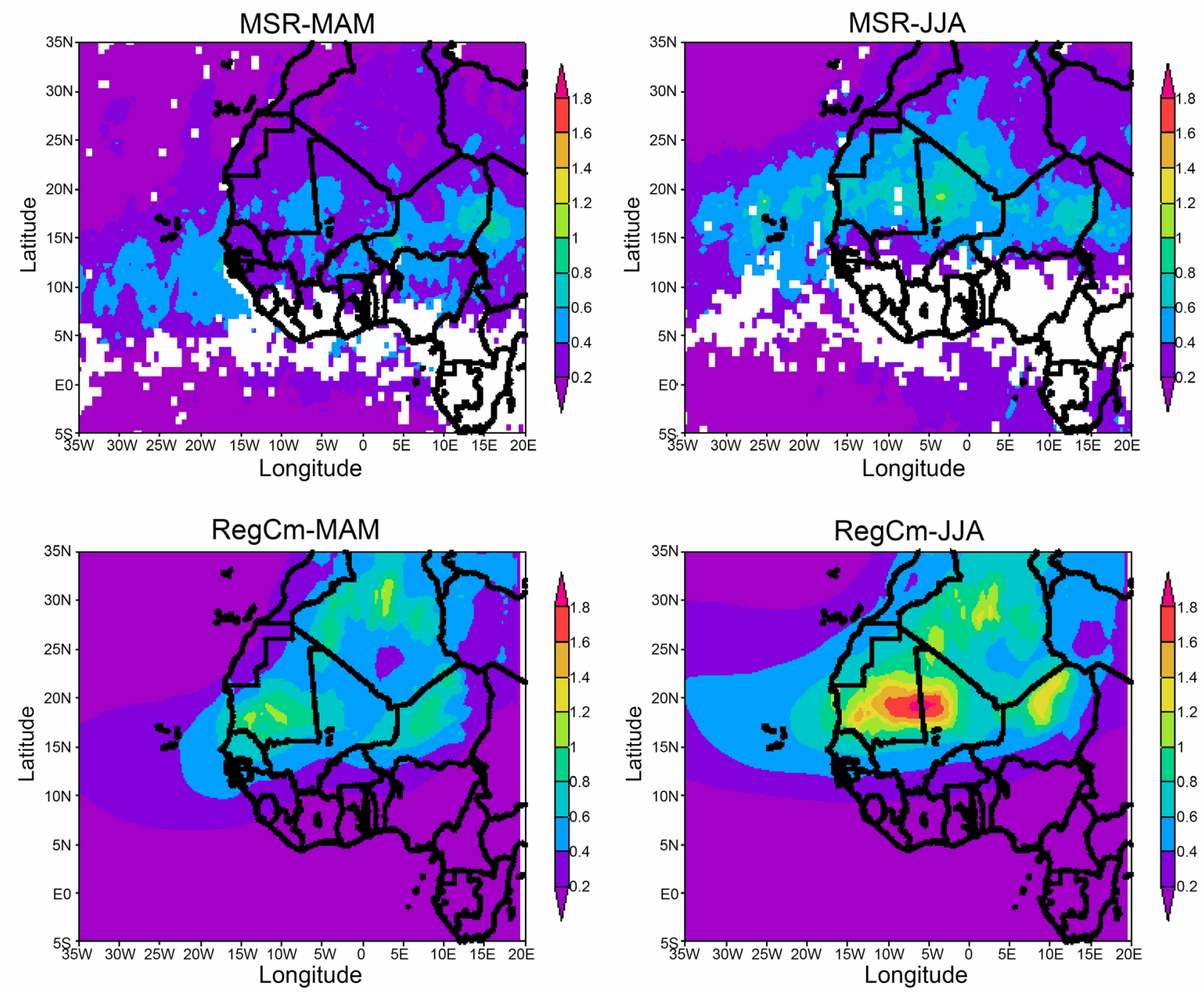

Figure 3. Seasonal cycle of the aerosol in Sahel using MISR sensor and RegCM3 output during 2006. Comparison between the dry (MAM) and rainy season (JJA).

instance, in Banizoumbou, the annual average of AOD is 0.54 for AERONET, 0.31 for MODIS and 0.36 for RegCM3.

In this section, we perform the validation of aerosol daily distribution (AOD $550 \mathrm{~nm}$ ) from the Julian day number. For this, we compare the AERONET in situ data with that of RegCM3 model for each of the stations in the region. Consequently, Figure 4 shows the daily cycle of AOD observed (AERONET) and simulated (RegCM3) in 2006. From East to West the locations are the AOD: at Banizoumbou (Niger), Ouagadougou (Burkina-Faso), Agoufou (Mali), Dakar (Senegal) and Sal (Cape Verde). Overall, RegCM3 follows the same trend as observations for these five stations. In agreement with [22] [23], we note that the model slightly overestimates the observation in the Western stations (Dakar and Capo Verde) and underestimated it for Eastern stations (Banizoumbou, Agoufou and Ouagadougou). In the continental stations (Eastern station), the model does not take into account the proximity of others sources of dust. These 

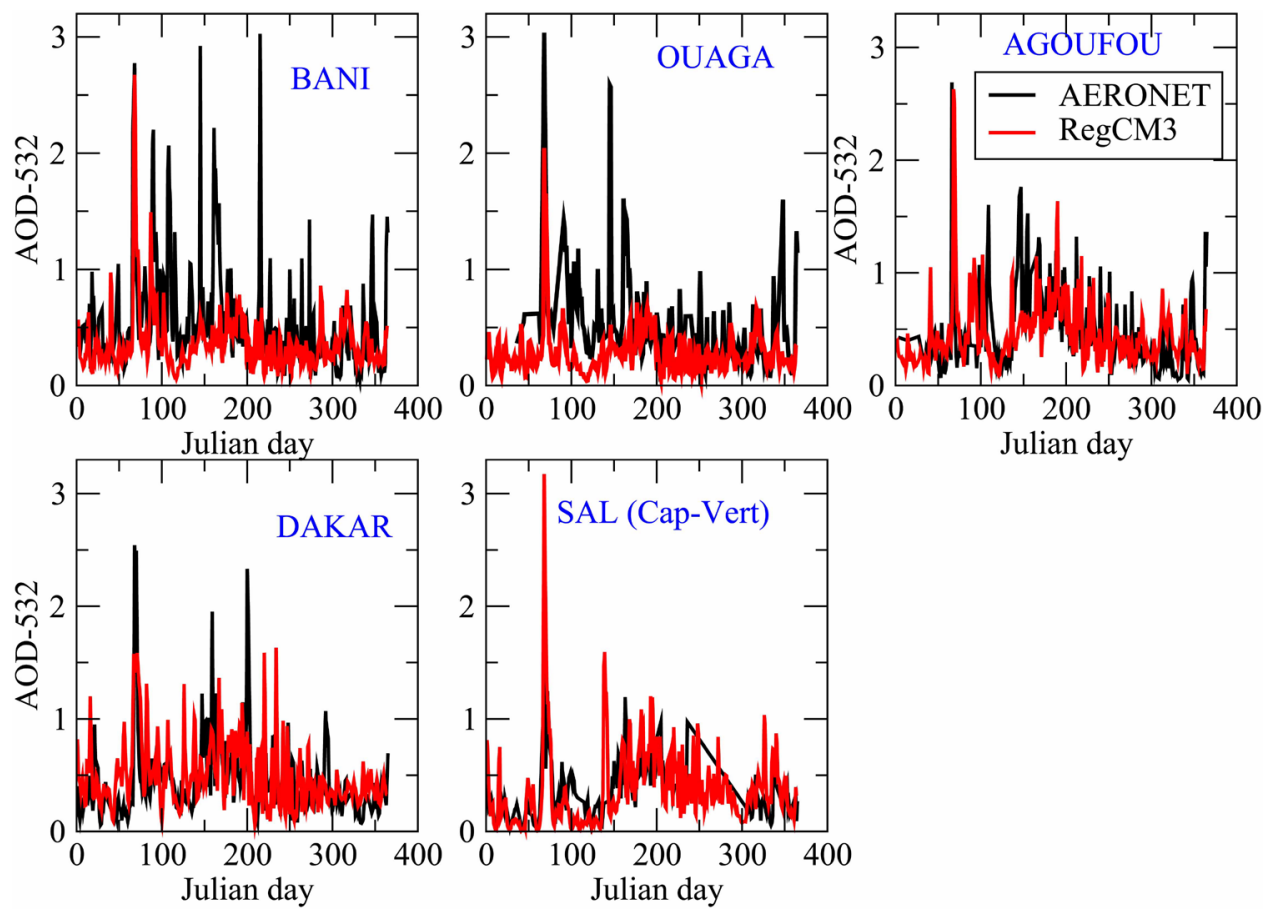

Figure 4. AOD daily evolution (Julian Day Number) in West Africa in 2006. Comparison between the AERONET observations (black) and RegCM3 simulation (red) at Banizoumbou (Niger), Ouagadougou (Burkina Fasso), Agoufou (Mali), Dakar (Senegal) and Sal (Cape Verde) stations.

are sources in the North (Northern Mauritania to Tamanrasset in Algeria) which may produce dust transportable toward Banizoumbou and Ouagadougou. Indeed, these stations are the nearest sources of biomass burning which may explain their presence. The high Angstrom coefficient shows that the biomass burning is more important in East than in the West of this region. A defect in the modeling of transport and deposition of dust may explain the overestimation of observation in the Western stations (Dakar and Cape. Verde). The statistical study shows disparities from east to west. The correlations are best on the coastal (Western) stations with scores of about $70 \%$ in Dakar and $51 \%$ in Sal (Cape Verde). This study is based on 150 days in Cape Verde and 277 days of observation in Dakar. The worst correlation is noted at Banizoumbou (39\%) with 324 AERONET observations days available. The correlation was $40 \%$ in Ouagadougou and $50 \%$ in Agoufou. For instance, during the dry season in 2006, a maximum of AOD is clearly visible on all stations between 9 and 14 March 2006 (JD = 69). The RegCM3 model is in good agreement with AERONET for this event.

\subsubsection{Dust Vertical Distribution}

In the following, we study the vertical distribution of dust with the model. Figure 5 shows the monthly cross section for RegCM3 extinction coefficient in Banizoumbou, Ouagadougou, Agoufou and Dakar stations. The results show that the dust extends from the surface to $300 \mathrm{hpa}(9 \mathrm{~km})$. The maximum of extinction is noted in spring and summer. Also, we observe two peaks in aerosol extinction during March and July for all stations. The Eastern stations (Banizoumbou and 

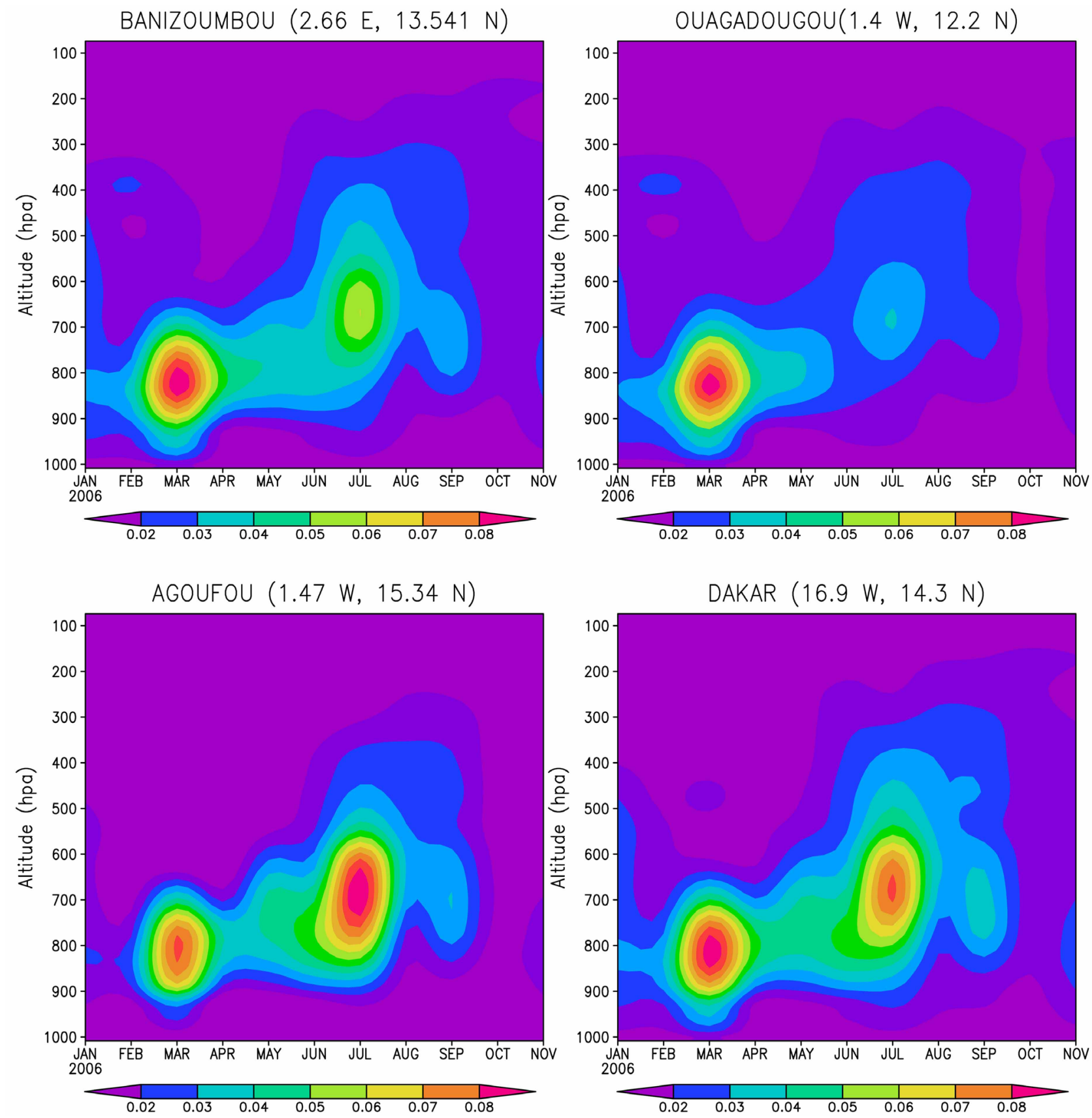

Figure 5. Monthly vertical cross section of aerosol extinction for different stations (Banizoumbou, Ouagadougou, Agoufou et de Dakar) by RegCM3 in West Africa during 2006.

Ouagadougou) are more affected by dust in March with an aerosol extinction value of the order of $0.08 \mathrm{~km}^{1}$ and these maximums are located in the lower levels around $850 \mathrm{hPa}(1.4 \mathrm{~km})$. However, the western stations are characterized in June (summer) by a maximum of dust located in the Saharan Air Layer toward $700 \mathrm{hPa}(9 \mathrm{~km})$.

To validate these vertical profiles, we represent in Figure 6 a comparison between RegCM3 simulation and the Lidar observation in Dakar. Overall, the model underestimated the measurements. In March, the transport of dust occurs 

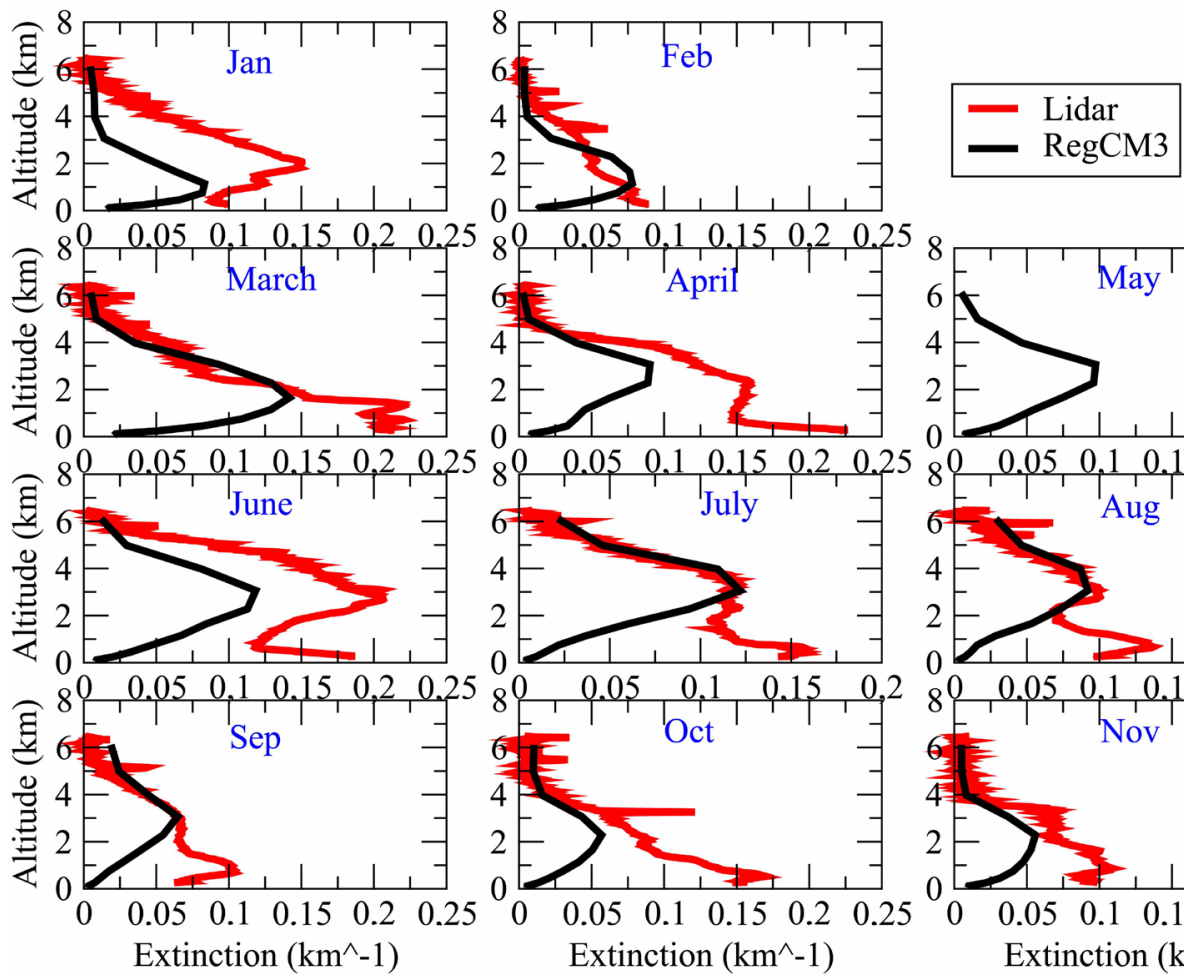

$500.05,0,1,0.15,0,2,0.25$
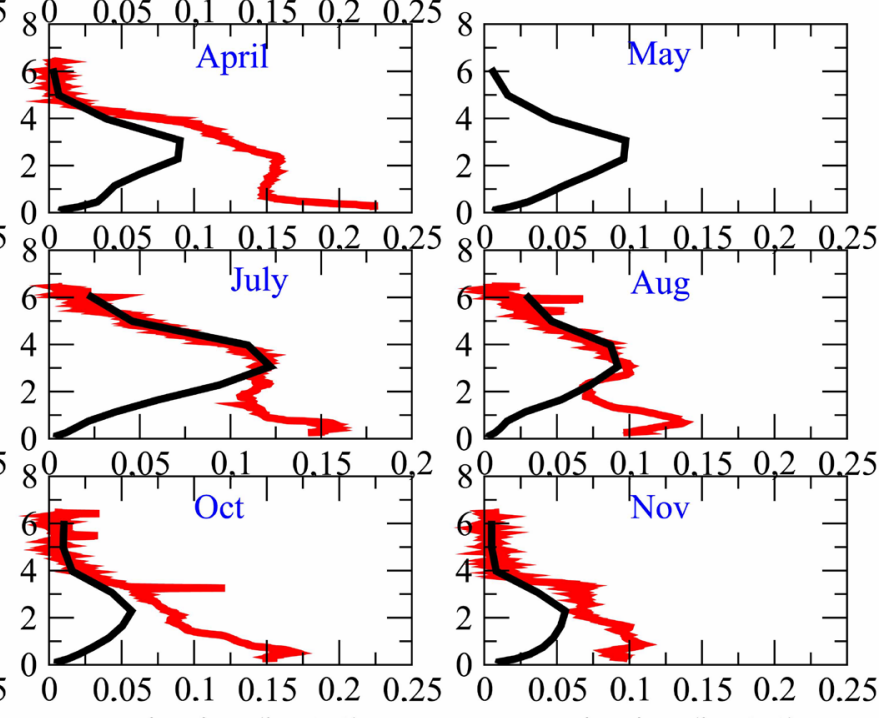

Figure 6. Comparison between monthly observed extinction profiles (Lidar retrieval) and simulated by RegCM3 at Mbour (Dakar) in 2006.

in the lower layers $(1-2 \mathrm{~km})$ and the model has difficulties to reproduce this lower-layer transport. During the wet season (June), RegCM3 simulates fairly well the aerosol layer located in the Saharan Air Layer (3 - $5 \mathrm{~km}$ ). In January (winter), the Lidar detected two aerosol layers above Dakar. The first is located around $1 \mathrm{~km}$ while the second around $2 \mathrm{~km}$. However, the model simulated only those located in the low layer at $1 \mathrm{~km}$. Recent studies have shown that this layer is composed of biomass burning aerosols [18] [22]. Consequently, February 2006 is characterized by an anomaly in AOD that could be due to a lack of transport in the lower layers [18]. However, RegCM3 does not show this anomaly of air masses transport and simulate a layer between 1.5 and $3 \mathrm{~km}$ with a maximum suppression of $0.08 \mathrm{~km}^{1}$.

For spring, the lidar has only worked for two months (March and April). In March, the model simulates a dust layer between 0.5 and $3.5 \mathrm{~km}$ with an extinction maximum of $0.14 \mathrm{~km}^{1}$. Because of a transport to a lower level, the Lidar is between 1.5 and $2.5 \mathrm{~km}$ with a maximum extinction of about $0.22 \mathrm{~km}^{1}$. However, RegCM3 simulates the data from April quite well. The dust layer is located, for the model and measurement, between 1 and $4 \mathrm{~km}$. We note that the maximum of aerosol extinction observed $\left(0.16 \mathrm{~km}^{1}\right)$ is twice as important as the RegCM3 simulation $\left(0.08 \mathrm{~km}^{1}\right)$. In April the model simulates quite well the level of aerosol transport while underestimating the total AOD.

June was the month with the most important dust loading in Mbour in 2006, with a maximum extinction of $0.22 \mathrm{~km}^{1}$ located at $3 \mathrm{~km}$ in the SAL (Saharan Air 
Layer). The Angstrom coefficient measured during month shows clearly a dust layer located between 2 and $5 \mathrm{~km}$ [21]. RegCM3 simulates well the shape of dust extinction profile in June. However, it detects dust concentrations below those of Lidar. The model estimates the maximum of extinction at $0.012 \mathrm{~km}^{1}$. From July to August, the model simulates very well the dust layer between 2 and $5 \mathrm{~km}$. The extinction maximums are detected for both products (RegCM3 and Lidar) with a value of $0.12 \mathrm{~km}^{1}$ in July and $0.10 \mathrm{~km}^{1}$ in August located around $3.5 \mathrm{~km}$. However, aerosols in the lower layer are not detected by the model. The same analysis is reproduced in autumn than in summer. Finally, the analysis cannot be made in the month of December because of unavailable data.

\subsection{Dust Climate Impact by RegCM3 Regional Climate Model}

In recent decades, several efforts were made to determine the radiative impact of dust on climate in West Africa [24]-[33].

Figure 7 shows the radiative impact of dust (shortwave) at the surface during

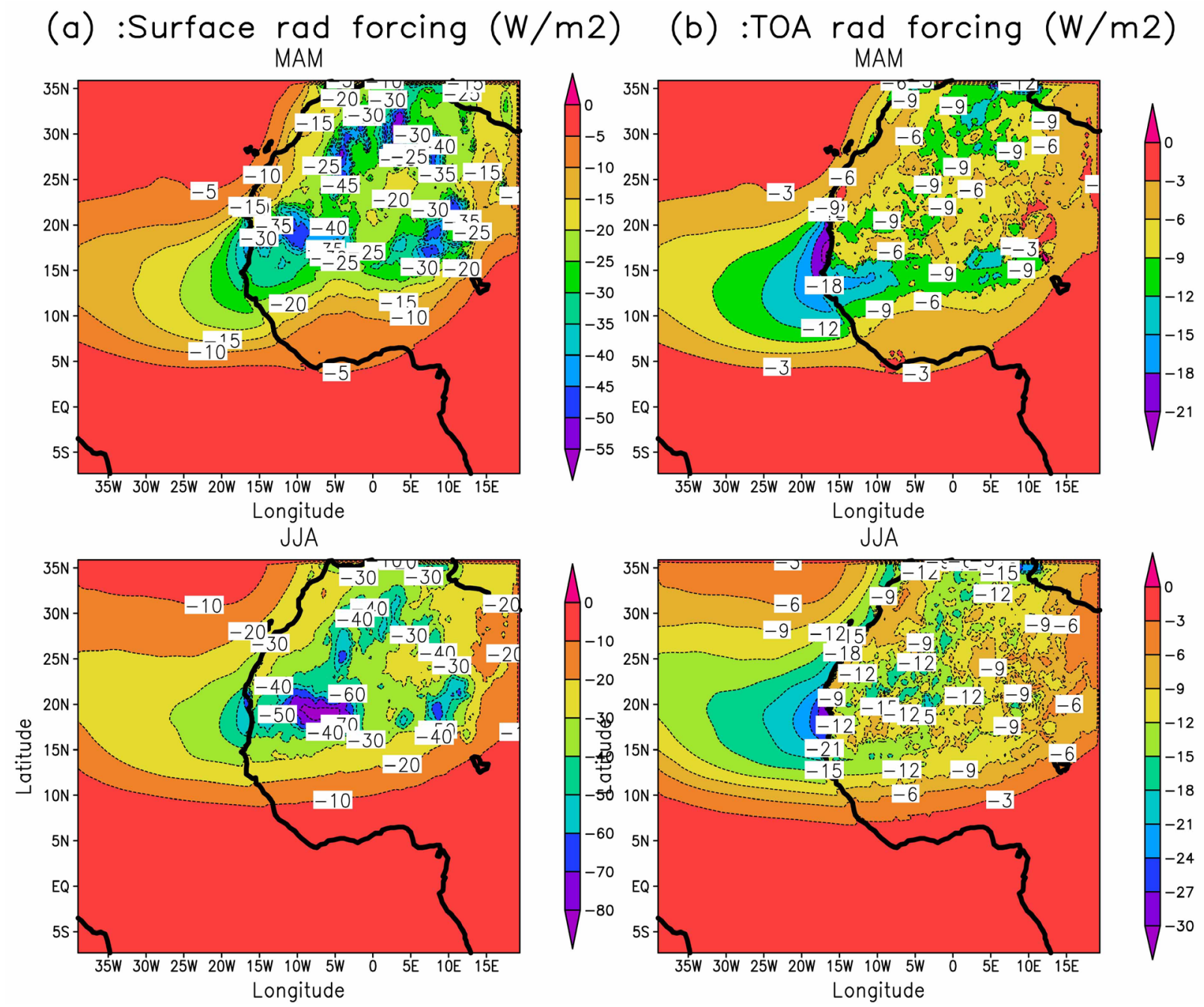

Figure 7. Dust radiative forcing over Sahel in 2006. Comparison between dry (MAM) and wet season (JJA) using RegCM3. (a) Radiation budget at the surface (left) and (b) Radiation budget at the height of atmosphere (right). 
the dry season (left) and the wet season (right). This study was conducted to the surface (BOA) and the top of the atmosphere (TOA). Overall, it shows cooling in this region with an average radiative forcing of about $-35 \mathrm{~W} / \mathrm{m}^{2}$ on the surface. Forcing is more important during the wet season than dry season to the surface. In dry season, the maximum is located north of the Mauritania-Mali border $\left(20^{\circ} \mathrm{N}\right)$ with a forcing of about $-45 \mathrm{~W} / \mathrm{m}^{2}$. The explanation for this maximum in Spring (MAM) results in the fact that the sources of aerosols are very active in this season. However, the maximum of cooling is registered near the source of dust in the wet season with a radiative forcing of about $-80 \mathrm{~W} / \mathrm{m}^{2}$ at the Mali/Mauritania border. This maximum is due to the coupled effects of Harmattan and convection in the summer [34].

Ultimately, we examine the impact of dust on meteorological parameters such as precipitation and surface temperature. Figure 8 illustrates the impact of dust on surface temperature (left) and rainfall (right) over $17^{\circ} \mathrm{W}$ and $20^{\circ} \mathrm{N}$ during the wet season (JJA) of the latitudes ( $\operatorname{Lon}=17^{\circ} \mathrm{W}-10^{\circ} \mathrm{E}$ ). The cooling causes a decrease in surface temperature over Sahel region. The maximum cooling is located near $21^{\circ} \mathrm{N}$ with an intensity about to $-1.7^{\circ} \mathrm{K}$. The increase of dust (can serve as cloud condensation nuclei) favored the indirect effect. Rainfall has decreased by $0.6 \mathrm{~mm} /$ day between $5^{\circ} \mathrm{N}$ and $15^{\circ} \mathrm{N}$ during JJA. These results are consistent with recent work indicating that the dust causes a reduction in temperature [35] [36] [37] by their direct effect and a drought (rain reduction) of their indirect effect [38] [39] [40].
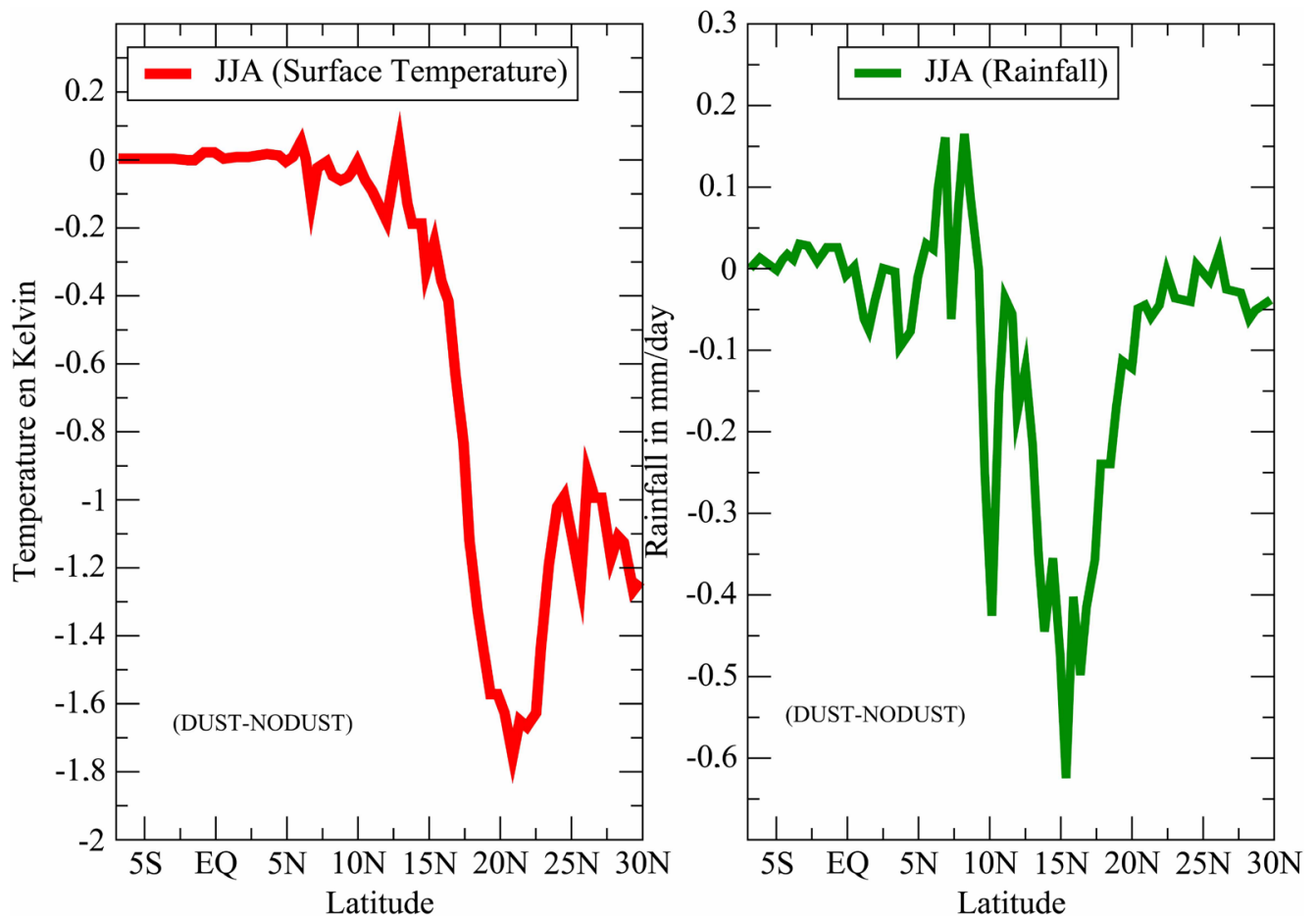

Figure 8. Impact of dust on the surface temperature (red in kelvin) and rainfall (green in $\mathrm{mm} /$ day) in West Africa during summer 2006 (JJA). Difference between dusty and no-dusty atmosphere as a function of the latitudes $\left(\mathrm{Lon}=17^{\circ} \mathrm{W}-10^{\circ} \mathrm{E}\right)$ using RegCM3. 


\section{Conclusion}

RegCM3 regional model was used to simulate and evaluate the impact of dust on climate parameters over Sahel. Ground (AERONET and LIDAR) and satellite (MODIS, MISR) measurements are used to validate this model. Dust season extends between March and October. There were two maxima: one during the dry season (March) and another during the wet season (July). The dust is located in the lower layers $(1-2 \mathrm{~km})$ in the dry season and in the Saharan Air Layer (3 - 5 $\mathrm{km}$ ) during the boreal summer. However, the model reproduces poorly the transport and sedimentation of dust in the lower layers $(<2 \mathrm{~km})$ mainly in dry season. Dust impact on climate found these particles favored a cooling. The maximum in radiative forcing is located around $18^{\circ} \mathrm{N}-20^{\circ} \mathrm{N}$, with values of about $-80 \mathrm{~W} / \mathrm{m}^{2}$ in June - July - August (JJA) and $-40 \mathrm{~W} / \mathrm{m}^{2}$ at the surface during March-April-May (MAM). Dust induces a reduction of rainfall in the order of about $-0.65 \mathrm{~mm} /$ day and the surface temperature of $-1.9^{\circ} \mathrm{K}$ near $15^{\circ} \mathrm{N}$ during the rainy season. And finally, this study has shown that proliferation of dust will increase à probability of drought in Sahel. Nevertheless, this model has difficulty in reproducing the dust in the atmosphere low layers. Therefore it is not suitable for air pollution studies.

\section{Acknowledgements}

We thank the AERONET team for the availability of aerosol parameters data. Thanks are also due to LOA-Lille (France), for the availability of Lidar data. This work was supported by Cheikh Anta Diop University.

\section{Conflicts of Interest}

The authors declare no conflicts of interest regarding the publication of this paper.

\section{References}

[1] IPCC (2001) Intergovermental Panel of Climate Change. Climate Change. The Scientific Basis.

[2] Rushingabigwi, G., Nsengiyumva, P., Sibomana, L., Twizere, C. and Kalisa, W. (2020) Analysis of the Atmospheric Dust in Africa: The Breathable Dust's Fine Particulate Matter PM2. 5 in Correlation with Carbon Monoxide. Atmospheric Environment, 224, Article ID: 117319. https://doi.org/10.1016/j.atmosenv.2020.117319

[3] Salvador, P., Molero, F., Fernandez, A.J., Tobías, A., Pandolfi, M., Gómez-Moreno, F.J. and Querol, X. (2019) Synergistic Effect of the Occurrence of African Dust Outbreaks on Atmospheric Pollutant Levels in the Madrid Metropolitan Area. Atmospheric Research, 226, 208-218. https://doi.org/10.1016/j.atmosres.2019.04.025

[4] Aziz, S.C.A., Ma, X., Kanike, RK., Jia, H., Tang, Y. and Sha, T. (2020) Evaluation of Dust Extinction and Vertical Profiles Simulated by WRF-CHEM with CALIPSO and AERONET over North Africa. Journal of Atmospheric and Solar-Terrestrial Physics, 199, Article ID: 105213. https://doi.org/10.1016/j.jastp.2020.105213

[5] Vogel, B., Panitz, H.J. and Vogel, H. (2016) Reducing the Uncertainties of Climate 
Projections: High-Resolution Climate Modeling of Aerosol and Climate Interactions on the Regional Scale Using COSMO-ART: Interaction of Mineral Dust with Atmospheric Radiation over West-Africa. In: High Performance Computing in Science and Engineering, Springer, Cham, 601-607. https://doi.org/10.1007/978-3-319-47066-5 41

[6] Kaufman, K.Y., Koren, I., Remer, L., Tanré, D. and Ginoux, P. (2005) Dust Transport and Deposition Observed from the Terra-Moderate Resolution Imaging Spectroradiometer (Modis) Spacecraft over the Atlantic Ocean. Journal of Geophysical Research, 110, D10S12. https://doi.org/10.1029/2003JD004436

[7] Holben, B., Eck, T., Sluster, I., Tanre, D., Buis, J., Setzer, A., Vermote, E., Reagan, J., Kaufman, K., Nakajima, T., Jankoviak, I. and Smirmov, Z. (1998) Aeronet: A Federated Instrument Network and Data Archive for Aerosol Characterization. Remote Sensing of Environment, 66, 1-16. https://doi.org/10.1016/S0034-4257(98)00031-5

[8] Haywood, J., Osborne, S., Francis, P., Keil, A., Formenti, P., Andrea, M. and Kaye, P. (2003) The Mean Physical and Optical Properties If Regional Haze Dominated by Biomass Burning Aerosol Measured from c-130 Aircraft during Safari 2000. Journal of Geophysical Research, 108, 8473. https://doi.org/10.1029/2002JD002226

[9] Joussaume, S. (1990) Three-Dimensional Simulations of the Atmospheric Cycle of Desert Dust Particles Using a General Circulation Model. Journal of Geophysical Research, 95, 1909-1941. https://doi.org/10.1029/JD095iD02p01909

[10] Miller, R. and Tegen, I. (1998) A GCM Study on the Interannual Variability of Soil dust Aerosol. Journal of Geophysical Research, 103, 25975-25995. https://doi.org/10.1029/98JD02345

[11] Alfaro, S. and Gomes, L. (2001) Modeling Mineral Aerosol Production by Wind Erosion: Emission Intensities and Aerosol Size Distributions in Source Areas. Journal of Geophysical Research, 106, 18075-18084. https://doi.org/10.1029/2000JD900339

[12] Dobricic, N.S. (1996) A Model for Long-Range Transport of Desert Dust. Monthly Weather Review, 124, 2537-2544. https://doi.org/10.1175/1520-0493(1996)124<2537:AMFLRT>2.0.CO;2

[13] Giorgi, F, Marinucci, M.R., De Canio, G. and Bates, G.T. (1993) Development of a Second Generation Regional Climate Model (RegCM2): Boundary Layer and Radiative Transfer Processes. Monthly Weather Review, 121, 2794-2813. https://doi.org/10.1175/1520-0493(1993)121<2794:DOASGR >2.0.CO;2

[14] Zakey, A.S., Solmon, F. and Giorgi, F. (2006) Implementation and Testing of a Desert Dust Module in a Regional Climate Model. Atmospheric Chemistry and Physics, 6, 4687-4704. https://doi.org/10.5194/acp-6-4687-2006

[15] Pal, J.S., Small, E.E. and Eltahir, E.A.B. (2000) Simulation of Regional-Scale Water and Energy Budgets: Representation of Subgrid Cloud and Precipitation Processes within REGCM. Journal of Geophysical Research: Atmospheres, 105, 567-594. https://doi.org/10.1029/2000JD900415

[16] Konaré, A., Zakey, A.S., Solmon, F., Giorgi, F., Rauscher, S., Ibrah, S. and Bi, S. (2008) A Regional Climate Modelling Study of the Effects of Desert Dust on the West African Monsoon. Journal of Geophysical Research, 113, D12206. https://doi.org/10.1029/2007JD009322

[17] Leon, J.F., Derimian, Y., Chiapello, I., Tanre, D., Podvin, T., Chatenet, B., Diallo, A. and Deroo, C. (2009) Aerosol Vertical Distribution and Optical Properties over Mbour (16.96 w, 14.39 n), Senegal from 200 to 2008. Atmospheric Chemistry and Physics, 9, 9249-9261. https://doi.org/10.5194/acp-9-9249-2009

[18] Salomonson, V.V., Barnes, W.L., Maymon, P.W., Montgomery, H.E. and Ostrow, 
H. (1989) MODIS: Advanced Facility Instrument for Studies of the Earth as a System. IEEE Transactions on Geoscience and Remote Sensing, 27, 145-153. https://doi.org/10.1109/36.20292

[19] Diner, D., Beckert, D.C., Reilly, T.H., Bruegge, J. and Conel, J.E. (1998) Multiangle Imaging Spectroradiometer (MISR) Instrument Description and Experiment Overview. IEEE Transactions on Geoscience and Remote Sensing, 36, 1072-1087. https://doi.org/10.1109/36.700992

[20] Ginoux, P., Chin, M., Tegen, I., Prospero, J., Holben, B., Dubovik, O. and Lin, S.J. (2001) Sources and Distributions of Aerosols Simulated with the Gocart Model. Journal of Geophysical Research, 106, 255-273. https://doi.org/10.1029/2000JD000053

[21] Camara, M., Jenkins, G. and Konare, A. (2010) Impacts of Dust on West African Climate. Atmospheric Chemistry and Physics, 10, 3053-3086.

https://doi.org/10.5194/acpd-10-3053-2010

[22] Haywood, J., Pelon, J., Formenti, P., et al. (2008) Overview of the Dust and Biomass Burning Experiment and African Monsoon Multidisciplinary Analysis Special Observing Period-0. Journal of Geophysical Research, 113, D00C17. https://doi.org/10.1029/2008JD010077

[23] Hsu, N., Herman, J. and Weaver, C. (2000) Determination of Radiative Forcing of Saharan Dust Using Combined Toms and Erbe. Journal of Geophysical Research, 105, 20649-20661. https://doi.org/10.1029/2000JD900150

[24] Mahowald, N., Luo, C., Corral, J. and Zender, C. (2003) Interannual Variability in Atmospheric Mineral Aerosols from a 22-Year Model Simulation and Observational Data. Journal of Geophysical Research, 108. https://doi.org/10.1029/2002JD002821

[25] Tompkins, A., Cardinali, C., Morcrette, J.J. and Rodwell, M. (2005) Influence of Aerosol Climatology on Forecasts of the African Easterly Jet. Geophysical Research Letters, 32, L10801. https://doi.org/10.1029/2004GL022189

[26] Yoshioka, M, Mahowald, N.M., Conley, A.J., Collins, W.D., Fillmore, D.W., Zender, C.S. and Coleman, D.B. (2007) Impact of Desert Dust Radiative Forcing on Sahel Precipitation: Relative Importance of Dust Compared to Sea Surface Temperature Variations, Vegetation Changes, and Green House Gas Warming. Journal of Climate, 20, 1445-1467. https://doi.org/10.1175/JCLI4056.1

[27] Paeth, H. and Feichter, J. (2006) Greenhouse-Gas versus Aerosol Forcing and African Climate Response. Climate Dynamics, 26, 35-54. https://doi.org/10.1007/s00382-005-0070-Z

[28] Mallet, M., Tulet, P., Serça, D., Solmon, F., Dubovik, O., Pelon, J., Pont, V. and Thouron, O. (2009) Impact of Dust Aerosols on the Radiative Budget, Surface Heat Fluxes, Heating Rate Profiles and Convective Activity over West Africa during March 2006. Atmospheric Chemistry and Physics, 9, 7143-7160. https://doi.org/10.5194/acp-9-7143-2009

[29] Lavaysse, C., Chaboureau, J.P. and Flamant, C. (2011) Dust Impact on the West African Heat Low in Summertime. Quarterly Journal of the Royal Meteorological Society, 137, 1227-1240. https://doi.org/10.1002/qj.844

[30] Lau, K., Kim, K., Sud, Y. and Walker, G. (2009) A GCM Study of Responses of the Atmospheric Water Cycle of West Africa and the Atlantic to Saharandust radiative Forcing. Annals of Geophysics, 27, 4023-4037. https://doi.org/10.5194/angeo-27-4023-2009

[31] Marcella, M.P. and Eltahir, E.A. (2014) The Role of Mineral Aerosols in Shaping the Regional Climate of West Africa. Journal of Geophysical Research: Atmospheres, 
119, 5806-5822. https://doi.org/10.1002/2012JD019394

[32] Zhao, C., Liu, X., Ruby Leung, L. and Hagos, S. (2011) Radiative Impact of Mineral Dust on Monsoon Precipitation Variability over West Africa. Atmospheric Chemistry and Physics, 11, 1879-1893. https://doi.org/10.5194/acp-11-1879-2011

[33] Drame, M., Jenkins G.S., Camara, M. and Robjhon, M. (2011) Observations and Simulation of a Saharan Air Layer Event with a Midtropospheric Dust Layer at Dakar, Senegal, 6-7 July 2010. Journal of Geophysical Research, 116. https://doi.org/10.1029/2011JD016368

[34] Tegen, I. and Fung, I. (1994) Contribution to the Atmospheric Mineral Aerosol Load from Land Surface Modification. Journal of Geophysical Research, 100, 18707-18726. https://doi.org/10.1029/95JD02051

[35] Charlson, R.J., Schwartz, S.E., Hales, J.M., Cess, R.D., Coakley, J.A., Hansen, J.E. and Hofmann, D.J. (1992) Climate Forcing by Anthropogenic Aerosols. Science, 255, 423-430. https://doi.org/10.1126/science.255.5043.423

[36] N’Datchoh, E.T., Diallo, I., Konare, A., Silue, S., Ogunjobi, K.O., Diedhiou, A. and Doumbia, M. (2018) Dust Induced Changes on the West African Summer Monsoon Features. International Journal of Climatology, 38, 452-466. https://doi.org/10.1002/joc.5187

[37] Twomey, S. (1974) Pollution and the Planetary Albedo. Atmospheric Environment, 8, 1251-1256. https://doi.org/10.1016/0004-6981(74)90004-3

[38] Albrecht, B.A. (1989) Aerosols, Cloud Microphysics, and Fractional Cloudiness. Science, 245, 1227-1230. https://doi.org/10.1126/science.245.4923.1227

[39] Ackerman, A.S., Kirkpatrick, M.P., Stevens, D.E. and Toown, O.B. (2004) The Impact of Humidity above Stratiform Clouds on Indirect Aerosol Climate Forcing. Nature, 432, 1014-1017. https://doi.org/10.1038/nature03174

[40] Senghor, H., Machu, É., Durán, L., Jenkins, G.S. and Gaye, A.T. (2020) Seasonal Behavior of Aerosol Vertical Concentration in Dakar and Role Played by the Sea-Breeze. Open Journal of Air Pollution, 9, 11-26.https://doi.org/10.4236/ojap.2020.91002 